\title{
Investigation and Implementing on Photovoltaic Systems in North Cyprus
}

\author{
Omer Damdelen $^{1 *}$, Ugur Seker ${ }^{1}$ \\ ${ }^{\mathbf{1}}$ School of Engineering, Faculty of Civil Engineering, Cyprus International University, Nicosia, Cyprus (ORCID: 2008-2012-5063-7303)
}

(Final form 30 September 2020)

(DOI: 10.31590/ejosat.802784)

ATIF/REFERENCE: Damdelen O. \& Seker, U. (2020). Investigation and Implementing on Photovoltaic Systems in North Cyprus. European Journal of Science and Technology, (Special Issue), 380-395.

\begin{abstract}
Energy is the golden thread that connects economic growth, increased social equity, and an environment that allows the world to thrive. Access to energy is a necessary precondition to achieving many development goals that extend far beyond the energy sector, eradicating poverty, increasing food production, providing clean water, improving public health, enhancing education, creating economic opportunity. The transition to sustainable energy systems also presents one of the greatest investment opportunities of the 21 st century. Development is not possible without energy, and sustainable development is not possible without sustainable energy. This research focuses on the possibility to improve the technology in Cyprus and to investigate about the options from the actual company, which is Cyprus Turkish Electricity Utility Company (KIB-TEK), responsible for producing, transmitting and distributing electricity to the consumers in North Cyprus. The research investigated the Photovoltaic system in North Cyprus. Photovoltaic is a method of electricity production that does not use nor releases harmful substances to the environment. It is one of the production systems commonly called clean energy. If the Middle Eastern countries like Cyprus, where high solar energy potential exists, the real situation shows a lack of developments about this technology. The aim is to find out the best solar energy system that suits with climatically conditions, economic conditions and to make people believe that the investment will be rewarded at the end. Considering the situation of North Cyprus, the urgent necessity of a new electric system will be important for the future of the environment and for the European standard. As a result this context, the issue of Northern Cyprus un-consideration of renewable energy is a big concern depends renewable energy to achieve sustainable environmentally friendly buildings. Lack of reliable renewable energy source, requires the use of photovoltaic technology. The application of this technology in North Cyprus, will lead to social sustainability and therefore cause an increase in the foreign trade market and business opportunities will dramatically increase the sustainability of the building as a unit.
\end{abstract}

Keywords: Photovoltaic system, clean energy, European standard.

\section{Introduction}

Solar energy is clean and renewable, produced directly using the energy radiated from the Sun to Earth. Every moment the Sun transmits on the earth orbit 1367 watts per square meter. The average solar radiation at European latitudes is about 200 watts / sq. It follows that the average power radiated per square meter on Earth at any instant is greater than 50 million Gw. (one Gw is the energy produced at full capacity of a large power station). The amount of solar energy, which arrives on earth, is huge, about ten thousand times greater than all the energy used by humanity. The developed countries introduced many regulations in order to limit the exhaust emissions from the power units, but Northern Cyprus is dependent on imported fossil. Sustainable, environmentally friendly and

\footnotetext{
${ }^{*}$ Corresponding Author: School of Engineering, Faculty of Civil Engineering, Cyprus International University, Nicosia, Cyprus, ORCID: 20082012-5063-7303, odamdelen@ ciu.edu.tr
} 
cheap alternatives are required. Renewable Energy sources can be alternative to fossil fuels as these sources are sustainable and environmentally friendly. My research will be focus on the possibility to improve the technology in Cyprus and to investigate about the options from the actual company, which is Cyprus Turkish Electricity Utility Company (KIB-TEK), responsible for producing, transmitting and distributing electricity to the consumers in North Cyprus. Nearly $80 \%$ of houses use solar thermal systems and a PV plant with 1.26 MW capacities was installed in 2011 but a new regulation approved by the authority of Cyprus Turkish in 2012 was put in practice in February 2014 [1].

Currently the energy generation capacity of the country is nearly $350 \mathrm{MW}$ and over $44 \%$ of this generation is consumed by residential sector alone for electricity. In anticipation of expectant increase in population based on trend and according to development of construction sectors, $1 \mathrm{GW}$ would be required to meet the country's demand by 2020[1]. It is important that most of this anticipated generation be from renewable energy technologies for sustainable environment. Solar energy sources potentials is very high in North Cyprus according to studies by yet under-utilized as most solar installations are specifically for water heating purpose especially during the winter period. The country has annual solar radiation estimated $1970 \mathrm{kWh} / \mathrm{m} 2$ at fixed angle of $28^{\circ}$ with nearly 300 sunny days [2]. This solar irradiation is much higher when compared to the sunniest area of Germany one of the world's solar photovoltaic largest market $[3,4]$. Sadly to note that despite this huge solar potentials, the country still depend entirely on imported fossil fuel notwithstanding its global price trend (BP, 2011) and associated GHG emissions [5]. The Objectives of research is to find most suitable system for North Cyprus by searching quality of the products and to compare on grid \& of grid system costs and sustainability. Another aim of the research will be to find funds for people to install the system and search how to install system that will be accepted by the laws in Northern Cyprus \& KIBTEK.

Cyprus, latitude $34^{\circ} 33^{\prime}-35^{\circ} 34^{\prime} \mathrm{N}$ longitude and $32^{\circ} 16^{\prime}-34^{\circ} 33^{\prime} \mathrm{E}$ after Sicily and Sardinia is the largest island in the East Mediterranean. After 1974 occupies $3355 \mathrm{~km} 2$ of the island. It is currently divided into two distinct political regions. Housing problems of conventional electricity use are common to both parts [3]. The design of solar power plants needs attention throughout the year. The climate is hot and dry with a strong humidity on summer climate and during winter the weather is cold and rainy [5]. On the island, based on historical data collected by the various meteorological stations we received solar radiation, around $7 \mathrm{kWh} / \mathrm{m} 2$ and in winter $3 \mathrm{kWh} / \mathrm{m} 2$ that photovoltaic panels are potential candidates to use the system. Although heavy conventional fossilbased energy investment in Northern Cyprus authorities, in particular has a significant interest in the use of solar energy among homeowners and factories. Electricity generation in Northern Cyprus depends solely on burning of imported fossil fuels and petroleum products contributing greatly to irreparable damage to the environment in the form of Greenhouse Gases (GHG) [5].

Currently the energy generation capacity of the country is nearly $350 \mathrm{MW}$ and over $44 \%$ of this generation is consumed by residential sector alone for electricity [7]. This generation is controlled and distributed by Turkish Cypriot electricity named Kib-Tek. In anticipation of expectant increase in population based on trend and according to development of construction sectors, $1 \mathrm{GW}$ would be required to meet the country's demand by 2020 [1]. It is important that most of this anticipated generation be from renewable energy technologies for sustainable environment, hence effort has been intensified by many research on different renewable energies that would serve this purpose. Solar energy sources potentials is very high in Northern Cyprus according to studies by yet underutilized as most solar installations are specifically for water heating purpose especially during the winter period[8]. The country has annual solar radiation estimated $1970 \mathrm{kWh} / \mathrm{m} 2$ at fixed angle of $28^{\circ}$ with nearly 300 sunny days [2]. This solar irradiation is much higher when compared to the sunniest area of Germany one of the world's solar photovoltaic largest market [3]. Sadly to note that despite this huge solar potentials, the country still depend entirely on imported fossil fuel notwithstanding its global price trend and associated GHG emissions [5]. The residential sector of the economy is the highest consumer of the generated capacity to be energy producer; feed in tariff system mechanism would be a viable tool as it has been successfully implemented in many neighboring European countries [9].

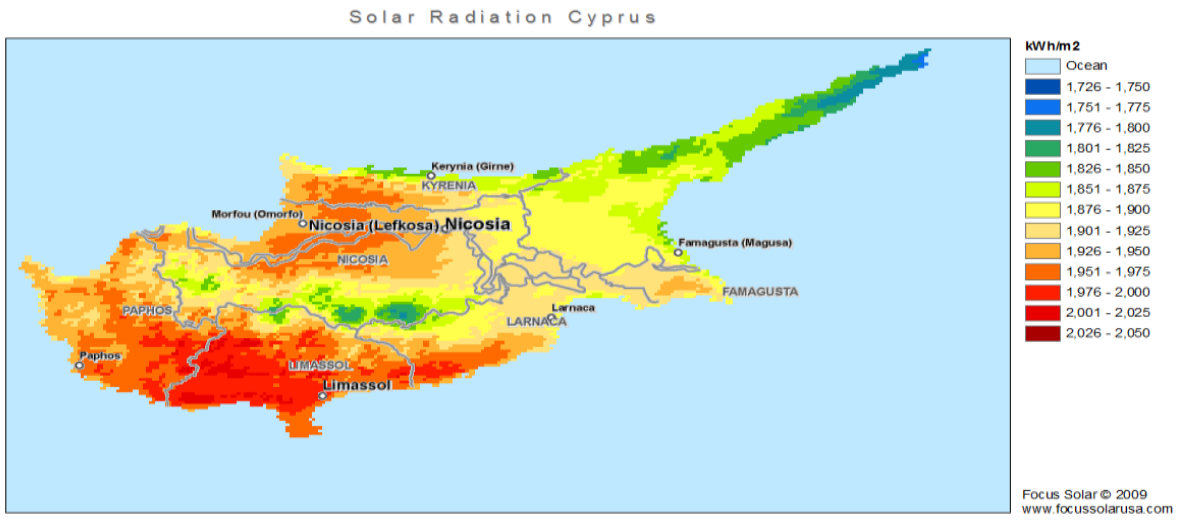

Figure 1. Solar Radiation Map of Cyprus

\section{Problem Definition}

The main problem is the lack of electricity energy and searching to alternative renewable energy systems in North Cyprus. It is an island and it is obvious that it has to produce its own electric. It can be alternative to get the electricity from countries which are close to island as a location such as Turkey. It is also still known that between Turkey and North Cyprus there is the process of discussing to get electric with cables under the sea. All those type of alternate energy takes time to build basic system such as power supply and infrastructure. Basically, more logical thing is to produce own electric and to get rid of being dependent on other countries. Every 
country has to produce own electric at least, because it is known each year the world is globalizing but on the other hand every year war rates are rising in those 'global' world. It is strategic position to produce own electric in this cases. In North Cyprus, it produce its own electric (Kib-Tek suppliers) since many years. It seems while producing own electric, problem is solved but in reality it is not. The main problem about the process of producing electricity is reducing the cost at the same time, provide good quality of energy and give it to customers with cheaper price in North Cyprus. Internet technology is providing to users to get the information's about the prices of electric energy worldwide, so users are aware of the prices in the world. The main duty of the Kib-Tek is providing electric to the customers. However, consumers are not happy from the facilities that are provided by Kib-Tek, also the prices of the electricity are expensive. So now, alternate energy systems might be the solution for North Cyprus which is suitable for Small Island in Mediterranean Sea. North Cyprus as a weather condition there is approximately 300 days sunny and that endless energy can produce energy to island and solar panel system is known as the most suitable system to provide electricity to the consumers. In last years, consumers are aware of the importance of solar energy systems.

\section{Research Question}

In the research, it is discussed below a few main questions about the most suitable renewable energy for North Cyprus, the role of Kib-Tek and the way of increase the efficiency in terms of economic, environmental and political.

One of the main question of the discussion is 'who is responsible for controlling and organizing a Photovoltaic Systems in North Cyprus?'. The main role is belongs to government but literally Kib-Tek can be responsible from the all issue. Kib-Tek authority is to supply the electric energy to the customers. It has to take into consideration in long term period, the benefits of on-grid and off-grid systems and its' suitable places to install, for instance in location such as Karpas where power energy is not working properly, off-grid system is very useful. On the other hand, on-grid system which is providing advantages such as selling option to the utility is available, on-grid system users balance their electric consumption with getting back electric from utility company. Basically, reducing tax incentives should offer to attract industry to the regions by authorities. Maybe in the future, North Cyprus could be the position of exporting electric to the foreign countries.

The question can be asked "why the solar energy is usable and wind renewable energy system is not?" In terms of location of the island, only few places are getting wind and its' power is very low and not enough to get electric through that system all period of the year. However, for those reason, wind renewable energy systems cannot be counted as an enough alternate energy system in North Cyprus. Only few times windy day a year cannot produce high standard of quality electric energy to consumers in North Cyprus. On the other hand the endless power of the sun is the main alternative energy providers and it has to be focused on how to increase the effectiveness of the sun with the using the last technological equipment's by the authorities. Basically, sun is undisputed fact that it has capability and ability to provide enough energy for that small island all period of the year.

Renewable solar panel energy systems are very expensive at the moment. At the thesis it has been discussed that in few years of time the prices would be decreased and after that consumers will pay more attention to implement those types of system. The question is "do Cyprus have enough spaces to implement renewable energy systems?". Solar panels covered a lot of spaces which is not suitable for Cyprus as a small island. It is obvious that the price will be getting cheaper, due to of supply-demand issue, so farmland should not be destroyed with the way of using solar system, so government has to pay more attention about the importance of the design of the solar panels such as making effort to find the way to install solar panels on the buildings.

In terms of economic benefits of solar system, while reduce the using of fuel oil, it directly contribute the economy. Instead of import the fuel oil, authority make an investment to the infrastructure, moreover it can create a job for locals. In terms of environmental impacts, fuel oil causes negative impacts to the nature even trees cannot grow around the power plant because of its negative waste gas from the pipes. In terms of political issue, the role of the government is very significant. However, investors have to encouraged by authority and invest for renewable energy business.

\section{Research Hypothesis}

This research aims to explain a positive relationship between the developing in power outage and increasing demand of solar power. In the future, renewable solar energy systems may well be the primary sort of energy. Increased the reliance on solar energy, it may decrease the pollution. In the present time, to find alternate energy is important because the fuel oil sources are threating countries with getting finished. There is strong relationship increasing in power outage and the increasing demand of solar energy. With the increasing of population, countries might be faced on with power outage and at the same time renewable energy has to play a significant role and cover that demanded energy. Basically, It is given every piece of information about different sorts of renewable energy system in the world and it can vary according to each country. Every country has their own characteristic features and different sunlight angle to the surface. For instance, in Mediterranean Sea area, solar panel systems are more logic to implement. Solar panel renewable energy can be main alternate renewable energy system to use but the thing is due to of lack enough land spaces, design of the solar panel play important role. Therefore, while using solar systems it is needed to avoid destroying farmland or other fertile land can produce a large number of good quality crops [10, 11]. At Limassol, Cyprus, there is a project that implemented wind tribunes to generate renewable energy. It has been researched feasibility, construction, operation and wind assessment. The result is to focusing on to get more electric with low wind and medium winds. It can be an alternate energy sources but just produce small amount of energy for consumers. So basically, wind tribune project was unsuccessful in Limassol [11]. In terms of weather condition, Italy is similar with Cyprus. In 2013, Italy has been at the first position to produce electricity through solar panels which is around 7\% and their aim is to make it double until 2030[12]. All these information that are collected have given an idea that solar panel system is the best renewable energy to install in North Cyprus. 


\section{Research Methodology}

This research is based on a qualitative methodology, because aim is to identify the phenomenon of the renewable energy system in North Cyprus. The process of doing research is identifying the weaknesses and strengths of PV models. The first step was to plan the discussions and choose the best research method with analyzing business models that dominate current solar market. It is also mentioned why a better renewable system is needed, how to explain and meet the questions 'why' and 'how'. Moreover, it is discussed for better understanding solar PV models which are related with the strengths, weaknesses, threats and awareness of existing business models. Finally, the last step for the research is how to compose a study to present and share the information result with audiences.

\section{Solar Panel Systems in North Cyprus}

\section{North Cyprus Authority}

The developing countries such as North Cyprus mostly use fuel oil in order to generate electricity. North Cyprus is a small country which produces its own electric energy. The local state utility company KIBTEK is responsible for generating distributing and selling the produced power to all consumers. KIB-TEK has 2x60 MW fuel oil fired steam power plants and 6x17, 5 MW fuel oil fired reciprocating diesel engine power plants. The company has also three gas turbines which are not used because of low efficiency and high operating cost. A private company AKSA, which has 8x17.5 MW fuel oil fired diesel power plants, meets the additional requirement of the country's energy need and sells the electrical energy to the utility company KIB-TEK [13, 14]. North Cyprus has no strict rules about environmentally friendly power generation systems. The KIB-TEK has financial problems so low quality and high sulphur content fuel (fuel oil No: 6, 3.5 \% Sulphur content by weight) is bought and burned in power plants to generate electricity. Therefore the emissions are quite high. Total power capacity of KIB-TEK is about 350 MW. In June 2012, the peak load reached to $280 \mathrm{MW}$. The reserve power capacity is not enough for demand side security therefore new investments are unavoidable. North Cyprus is dependent on imported fossil. Solar Energy Use Terms of Cyprus is determined by regulations in Law No. 47/2011. The purpose of this regulations, "Renewable Energy Law" to determine the principles for implementation. This regulations made only principle for producing energy from renewable energy sources and methods include the administration and control rules [14].

\section{The Basic Principles of North Cyprus Renewal Energy Regulations [15]}

- Each whatever purpose, it is subject to approval by the authority of electricity production from renewable energy sources.

- In cases where electricity will be produced for commercial purposes Council of Ministers allowed by Cyprus Turkish authority in a decree removing defined in accordance 4th of the Board of Electricity Act.

- Corporate consumers, provided you can get the permission of the authority of generating electricity from renewable energy sources for their needs.

- In case of excess consumption of electricity to the grid more than the needs of the institution any payments by energy consumers will be made to the Authority.

- Heat production from renewable energy sources for commercial purposes is subject to the approval of the Cyprus Turkish authority.

- To accomplish the trade of electrical and thermal energy produced from renewable energy sources, production and trade was allowed in respect of natural or legal persons receiving RES Certificate is required. Energy trade cannot be made of non-RES certificates.

- Commercial purposes will be allowed on the basis of renewable energy sources and installed capacity of electricity generation plant types, determined by the Board and the authority obtained the opinion of related institutions and organizations.

- The authority for the next year will be allowed in December of each year makes determining capacity for renewable energy sources and is published on the Ministry's website.

\section{Permission Principles of North Cyprus Renewal Energy Regulations [14, 15]}

\section{For Permit Applications [15]}

- Permission to produce electricity or thermal energy from renewable energy sources will be taken as a reference is made to the authority by the board and proposed procedures will be determined by the authority.

- Ability to produce energy from renewable energy sources by the Ministry in relation to a permit which are received by the authority will be required by the Board and defined in form and content.

- The duration of the permits shall be not less than six months from the date of registration with the Board is determined depending on the project type and size by the authority with the proposal.

- The above article given in the facility permit applicants who cannot establish within the period of re-authorization is entitled to make a request for it.

- Permits are issued free of charge, it will be delivered to the applicant.

- The license shall be kept by the owner during the permit and inspections, it will be presented to the person appointed to do the audit.

\section{RES (Renewal Energy Source) Permit Applications [15]}

- Energy production of electricity or thermal energy from renewable energy sources and / or determination of the source type of trade and with the permission of production to follow legal person and / or organization's consumers, from the date of 
Avrupa Bilim ve Teknoloji Dergisi

application by the authority showing the production of electricity or heating capacity from renewable energy sources in a calendar month Renewable Energy Resources Production Permit (RES) is issued.

- $\quad$ RES permit the person and are prepared depending on address and another address it cannot be transferred.

- There will be no connection to the network (off-grid) to produce renewable energy plants are considered in their terms by the Board and are allowed by the authority.

- RES applications are to be made in order to obtain the document, made by the authority will propose procedures to be determined by the Board.

- Applications must be signed and submitted to the authority with a receipt of the official seal.

- Submission of applications and receipt for any tax, stamp duty, fees or charges are not paid.

- RES certificates are issued free of charge, it will be delivered to the applicant.

- RES application, in form and content will be determined by the Board and the authority will suggest.

- RES certificates is valid for 20 years, may be submitted for renewal at the end of this time the RES certificates.

\section{Application of the energy produced from renewable energy sources, on Implementation of Policies and Procedures Audit and Administrative Sanctions [13, 14 and 15]}

- A facility that is designed to produce electricity from renewable energy sources to be used in all materials, equipment and parts can be imported into the country with the approval of the Board, or the approval of the Board in the country would give the conditions that can be produced. The Board is required when using the power that is given in accordance with this paragraph, if the gets some help from EMO Chamber.

- Grid connection of the plant to be established in order to produce electricity from renewable energy sources is made in accordance with the organization's current practices.

- The transfer of electricity produced from renewable energy sources of the Agency network, to be a valid and appropriate technical infrastructure for RES Certificate is made possible by virtue of proving Authority control is provided.

- Outside of the residential tariff, for electricity produced from renewable energy sources in the network to be transferred to the institution, the institution will need to be made an additional investment into the system in question, provided that the additional investment costs will be met by the project owner, is made by the institution.

- During the transfer of power of the institution network produced from renewable energy sources resulting from manufacturing plants or transmission or communication systems of any damage to any reason, the organization's system or if it is determined that such a risk, the Authority immediately and will cut any prior notice on the link without or allow any make the kinds of transactions. In this case, the person concerned will be notified in writing within three business days.

- The electrical and thermal energy produced from renewable energy sources in all trade related legislation, permit conditions and if there have been determined in accordance with the terms and conditions of RES certificates. If it was received as required security measures and this is been prepared measures of the plan for implementation and whether they display the appropriate procedure and the law and the supervising Ministry's task is been violated in any way by this Regulation.

- The Ministry pursuant to this article supervising the Police Headquarters, the relevant municipality office attached to the Ministry, institutions and / or organizations or any ministry that other necessary see, apartments, organization and / or made into consultation and cooperation with the organization and supervision of as necessary and safety it allows the execution.

- Inspections carried out in accordance with this Article, as notified in advance or without notice; on complaints made at any time of the day.

- $\quad$ RES document with the people, all public officials or officials tasked inspection in accordance with this article, helping to perform adequately of control and is obliged to provide the necessary ease and cooperation.

- Before starting the inspection, making checks disclose the identity of persons involved and to present to the people responsible for these tasks or official document proving that they control a facility is required.

- With regard to controls, the controls and detailed record is kept of the audit during the construction of this report the date, start and end times, details about the facility is controlled, and the tasks that are contained in the credentials of all the people prepared during the audit; and conclusions include considerations prominent in the control.

- Record signed by all the parties concerned and a copy of the report is given to the property owner or a person responsible for the facility.

- The officials who control the controls for elimination of the defects, resulting in the fourth part of law is located in the development of competent and responsible for supervising them and enforce the rules.

- All documents and other documents related to the audit shall be submitted to the Ministry and shall be kept by the Ministry. 
- Residential institutions in tariff consumers, their consumption of energy transfer to the corporate network as more is transferred to the next month $\mathrm{kWh}$ credit institutions to withdraw from the network and is billed in excess paid. The subscription will be terminated at the end of the calendar year or reset.

- Use the form of offsetting the cost of the network is determined by the Board and shall come into force with the approval of the Ministry.

\section{Environmental Overview of PV Panel in North Cyprus}

There are no doubt Installed PV cells or panels pose minimal risks to human health or the environment according to the Brookhaven National Lab and the Electric Power Research Institute [3]. In this case, the Occupational Health and Safety, in particular is one of the most important aspects of the use of individual PV technology in North Cyprus. PV cells are typically connection with copper wire coated with tin. Some PV panel manufacturers if released into the environment may cause risk to the environment and human health solders containing lead and other metals use. This step in the installation process usually vending module assembly as human exposure to these metals is not possible way. It is not available in North Cyprus, but this issue should be taken into account in the development of PV panels to the process, though. In addition, elution PV panels are heavy glass or plastic covering, this may be emitted in small amounts there is little risk of the semiconductor material. Looking at the two section explains the advantage in the PV industry, focused on environmental protection, use basic PV panels. Northern Cyprus media situation usually prepares the base photovoltaic platform in the best condition.

Table 1. Comparison of the Northern and Southern Cyprus of in the respect to economy, laws and adoption. [16, 17, 18, and 19]

\begin{tabular}{|c|c|c|}
\hline & South Cyprus \{Greek] & North Cyprus [Turkish] \\
\hline Renewal Energy Law & $\begin{array}{ll}\checkmark & \text { Enacted in line European } \\
\text { Union Legislations }\end{array}$ & $\begin{array}{llr} & \text { An outline has been } \\
\text { prepared but not yet } \\
\text { implemented. }\end{array}$ \\
\hline Photo-voltaic Adoption & $\begin{array}{ll}\checkmark & \text { Installations commenced } \\
& \text { from 2006. } \\
\checkmark & \text { Victual-in-tariff policy } \\
& \text { subsist. } \\
\checkmark & \text { PV panel engenderment } \\
& \text { facilities subsist. }\end{array}$ & $\begin{array}{ll}\checkmark & \text { No victual-in-tariff policy. } \\
\checkmark & \text { A few individual } \\
& \text { installation. }\end{array}$ \\
\hline Economy & $\begin{array}{ll}\checkmark & \text { Prosperous and diversified } \\
& \text { economy } \\
\checkmark & \text { Base for several offshore } \\
& \text { businesses } \\
\checkmark & \text { Good-developed tourism } \\
& \text { sector }\end{array}$ & $\begin{array}{ll}\checkmark & \text { Free market substructure } \\
\checkmark & \text { Physically incapacitated in } \\
& \text { terms of private and public } \\
& \text { investment } \\
\checkmark & \text { High shipping cost and } \\
& \text { lack of learned labor } \\
\end{array}$ \\
\hline
\end{tabular}

\section{Economic Overview of PV Panel in North Cyprus}

The purchase of a Photovoltaic system in North Cyprus characterizes a spending of investment resources at concrete time with hope of benefits in the form of electric energy distributed over future period, which is generally the life of the photovoltaic system. On the scale of the photovoltaic system for any given species, primarily of the value of the electricity produced may perform 10 to 25 periods $[20,21]$. Thus, the research presents the main problem, is how one measure the value of future benefits can. In addition, the subject diesel electric grill, fossil fuel electricity generators and alternative electricity supply with photovoltaic system in northern Cyprus, such as how to compare these values. The value of future benefits to recover the system at the end of life. The primary examples are the maintenance cost and the failed module. In addition, in the future a cost or benefit today is often a cost or benefit that is not equal to intuitively recognize the value of the same [21]. Postulate that the system value of electricity engendered for 25 years, which is available in North Cyprus market, there are supersession costs of 5000 TL in each 5 years.

For a photovoltaic system, the value of the engendered electricity is customarily determining by the evaded cost of the electricity that would otherwise need to be purchase [22]. Note that the annual electricity engenderment in kilowatt-hour from the photovoltaic system is implicitly included in this example through the tenaciousness of the electricity cost stream [22, 23 and 24]. A sum received or spent now has a present value, $(\mathrm{P})$; A sum spent or received at future time $(\mathrm{N})$; Years hence has future value $(\mathrm{F})$; If $(\mathrm{P})$ is invests at an interest rate of (i) percent per year, Then it is future value at the end of the first year is; $\mathrm{F}=\mathrm{P}+\mathrm{P} \mathrm{i}=\mathrm{P}(1+\mathrm{i})$; The future value at the end of the second year is $\mathrm{F}=[\mathrm{P}(1+\mathrm{i})](1+\mathrm{i})=\mathrm{P}(1+\mathrm{i}) 2$. In addition, the future value after $(\mathrm{N})$ years is $\mathrm{F}=\mathrm{P}+(1+\mathrm{i}) \mathrm{N}$. Conversely the present value of a future sum given by $\mathrm{P}=\mathrm{F}(1+\mathrm{i})-\mathrm{N}$. Equation $(\mathrm{P}=\mathrm{F}(1+\mathrm{i})-\mathrm{N})$ is shown that the present value of a sum received (N) years in the future is deductibles by the factor $(1+\mathrm{i}) \mathrm{N}$. When equations $\mathrm{F}=\mathrm{P}+(1+\mathrm{i}) \mathrm{N}$ and $\mathrm{P}=\mathrm{F}(1+\mathrm{i})$ - $\mathrm{N}$ refer to money deposited at interest."(i)" The factor is the interest rate offered by the bank, nevertheless once an investment in an energy system is being considering the factor referred to as a discount rate. The discount rate system owner puts the capital invested in the system and often calls the investor the opportunity cost; this is the next most attractive rate of return on investment is made in advance[22, 24]. 


\section{North Cyprus Photovoltaic Market Structure}

In the last few years, photovoltaic market has undergone a remarkable boom. More precisely, in the last two or three years, the photovoltaic market sixteen point six Giga watts of annual capacity added worldwide by about forty watts Gigi cumulative installed capacity reached[23, 24]. Photovoltaic energy, the European Union (EU) and the peak still be a part of a fully competitive anywhere in the world energy mix is an increasingly important part of the electrical system $[15,16]$. When using photovoltaic panels agreed to the EU regulations, Cyprus change $20 \%$ of the electricity supply to the Southern Part of the photovoltaic system. Photovoltaic panels are rapidly growing within the market for 2 years, it reflects the EU decision [23]. As shown Figure 4 interview with the Cyprus Company, it was discovered because of cheapness and attracts the most appropriate weight in the durability Monocrystalline photovoltaic market. On the other hand, there is no limit off-grid [25]. Since photovoltaic market is mainly the private sector. However, for on-grid system, they have to take influence from the government for a bi-directional electric meter assembly to install in their homes. KIB-TEK's total electricity generation capacity a $362.5 \mathrm{MW}$, Giga-watt $(1 \mathrm{GW})$ is estimated to increase from in 2020[13].

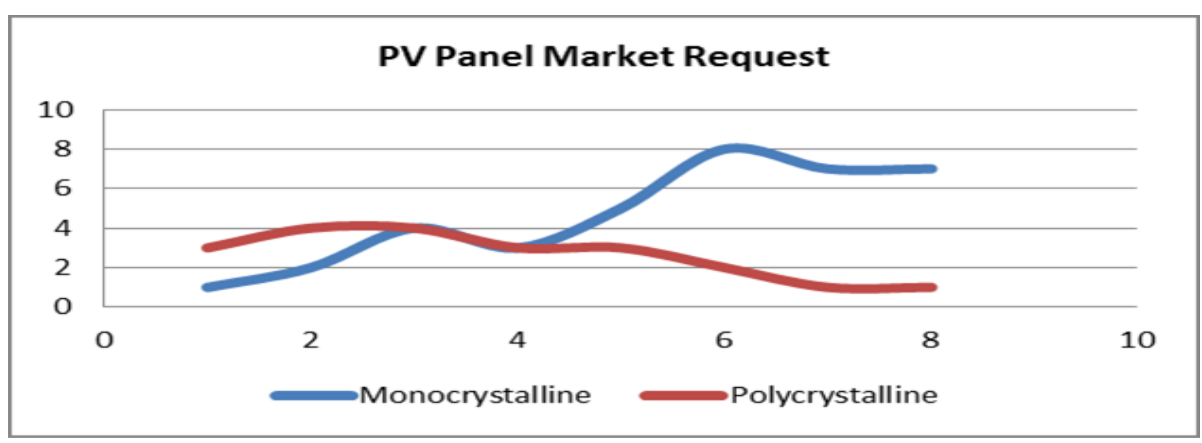

Figure 2. Assumption of Photovoltaic Panel Market Request for Mono and Polycrystalline in the North Cyprus

\section{North Cyprus Photovoltaic Strategy, Regulation Framework}

In 2009, despite the North Cyprus authority has not yet ratified it tries to prepare a policy for organizing editing and recording using renewable energy. By authorities as a sub after eight members and the president. These members are a person mechanical engineering, academic two person, a person from the electrical room, Economics and has to choose the order of the ministry of vice president [14]. In 2012 (legislation) and the (record) written by the North Cyprus authority and the position of (not yet approved) that has been approval. Basic strategy in North Cyprus is to reach $20 \%$ of the total energy by renewable energy instead [13]. President Bush in the entire construction industry in this scheme, but without the point of building type should penetrate the North Cyprus authority. There is no limit penetration but the government is obliged to publish newspapers and period begins 15 days to 6 months (private business) depends on the type of function. It focuses on security policy in Northern Cyprus and the EU standards [14, 23]. PV panels, such as selection and installation and performance to be declared by the government as whole KW domain, accept the amount of electricity produced and is obliged to extend the necessary equipment.

\section{Energy Efficiency Strategy Document of North Cyprus how people can apply (PV) Solar Energy System in North Cyprus Important Points}

\section{Creating Energy Efficiency Act and the relevant Regulations}

These actions will be implemented by the Authority of Energy. Energy production, transmission, distribution and consumption of energy, industrial enterprises, buildings, power generation plants, transmission and increasing the transport of energy efficiency with the distribution network and support the community in the development of energy-consciousness in general, covers the principles and procedures to be applied for the exploitation of renewable energy sources. Including energy performance in buildings regulations include the creation of legal infrastructure to ensure energy efficiency [26].

\section{Supporting the R \& D Activities for Renewable Energy}

These actions will be implemented by the Authority of Energy. In line with these actions, the Authority of Energy will perform support universities, CTCI and KTMMOB for R \& D activities. Energy efficiency a priority by the Authority of Energy and technology in the field of renewable energy sources should be the creation of financial resources for the promotion of public-private co-investors. This process should be supported in accordance with the products produced in the North Cyprus will provide energy efficiency.

\section{How People can apply (PV) Solar Energy System in North Cyprus}

\section{How to Take Renewable Energy Certificate}

To receive renewable energy certificates are needed to comply with the rules established by law. Permission to produce electricity or thermal energy from renewable energy sources will be held for reference shall be made to the Ministry and the Board will propose procedures to be determined by the Ministry.

For Permit Applications

A. Required Documents 
- The agreement to be concluded between the employer and an electrical engineer (3 copies).

- The cob or lease agreement specifies the name of the consumer.

- Site Plan.

- The KIB-TEK copy of the electricity bill. (Tariff 01 will not accept the invoices).

- Technical specifications.

- Power Project.

- KIB-TEK customers will be the name of the RES project with the same name.

B. Projects must be drawn according to the specifications prepared by the Renewable Energy Board.

C. Detailed settlement with symbols on the layout plan must have a plan. Group numbers and the specific properties of the PV panels should be written. Junction boxes and the distribution tables must be drawn.

D. Each group should be written in a single line diagram number and total power.

E. Section layout name in the legend required power $\mathrm{kW}$ on-grid and off-grid PV system must be written.

F. RES projects in advanced stages of the panel cannot be displayed.

G. Inverter power in the RES project shall not exceed $\pm 10 \%$ of panel power.

H. Hybrid projects (on-grid, off-grid inverters will not be accepted.

Assessment Procedure Process

Approval Process and Res Capacity Connectivity

- In the evaluation process provided assessments of the document can be done according to the rules of the KIB-TEK.

- Transformers AG (until 200kwp) + MV transformer is limited by the level of demand load 2/3 of the power and determination of the MV according to the formulation specified level connectivity rate.

- Connectivity to local transformer capacity according to the table for links in the region has been identified in the LV level. In case of this ratio will exceed $30 \%$ by the Regional Planning Authorities - MV / HV branch to inform to the authority

- Positive or negative written about the Ministry of KIB-TEK views.

Supervision Fee

- $\quad$ LV level to be connected to the electrical mains Solar Energy Systems, who have installed EMO (Chamber of Electrical Engineers) ATCEC with Certificate of Authority (Turkish Cypriot Electrical Contractors Union) will be presented by members of the KIB-TEK Control.

- $\quad$ Received from the relevant ministries, "Production License's submissions KIB-TEK's payment of the fee, depending on the predetermined inspection.

- $\quad$ Previously reported "Inverter Limit Notification Form, Information Statement, Standards " are filled in full.

- Supervision "Check Form" to be submitted to the KIB-TEK's regional directorship and should be complete by the relevant parties.

Safety Measures and Commissioning Process

- $\quad 200 \mathrm{kwp}$ loads on MV connection is made and Regional Level Project files opened by the Authority will apply the applicable procedures. The only line KIB-TEK Schemes approved by the project approval process.

- For loads up to Level 200kwp AG connection is made and Single Line Diagrams EMO (Chamber of Electrical Engineers) approved by. (Load Demands for power consumption other than housing KIB-TEK Legal Committee and / or limited by predetermined table)

- Solar Power Plant of GM-type cutter of the transformer ransacked condition that Circuit Breaker and the Relay to be used for SCADA selecting the type compatible with the system, the communication with RTU relays the Modbus, the RTUs KIB-TEK communication with the system is that the IEC 101 standard.

\section{Commissioning Process}

- Depending on the submission of YEK certificate, $1 \varnothing$ and/or $3 \varnothing$ issue of and final calculating of the meter made after the completion of commissioning procedures for the necessary tariff system and settlement "Net - Metering" Starting the process.

- The RES tariff customers ' existing work will be mechanical counters KIB-TEK, electronic counter without demanding any compensation.

The Requirements

Inverter Limit Value 
Table 2. Operating Frequency and Limit Values

\begin{tabular}{c|c|c}
\hline Limit Values Frequency $(\mathbf{H z})$ & Disable Delay Time (sec) & Working Status \\
\hline$>52$ & 3 & Out of Order \\
\hline $47,5-50,2$ & - & Normal Operation \\
\hline 47,5 & 0,5 & $\% 4$ Drop in Load $/ 0,1 \mathrm{~Hz}$ \\
\hline$>50,2$ & No Delay & \\
\hline
\end{tabular}

Table 3. Reactive Power Limit

\begin{tabular}{l|l}
\hline \multicolumn{1}{c|}{ Maximum Apparent Power (Smax) } & Power Factor $(\cos \theta)$ \\
\hline$<4 \mathrm{kVA}$ & 0,95 lagging $-0,95$ leading \\
\hline$>14 \mathrm{kVA}$ & 0,9 lagging $-0,9$ leading \\
\hline
\end{tabular}

Inverter Standards

$>$ VDE-AR-N 4105:2011-08 (General Access Rules)

> IEC 62109-1:2010 veya EN 62109-1 (Security-General)

IEC 62109-2:2010 veya EN 62109-2 (Security-Special)

$>$ IEC 61000-3 (Harmonics)

VDE0126-1-1 (Voltage and network monitoring) (Ministry of TRNC Energy)

$>$ Photovoltaic Standards

$>$ EN 61730-1: 2007

$>$ EN 61730-2: 2007

$>$ EN 61215:2005

$>$ EN 61646 (Flexible Panel)

$>$ IEC 61730-1: 2004

$>$ IEC61730: 2: 2004

$>$ IEC 61215: 2005

$>$ IEC 61646 (Flexible Panel)

$>$ IEC 61730-1: 2013

IEC 61730-2: 2014 (Authority of Northern Cyprus Energy)

$>$ Salt Spray Test

$>$ IEC 61701 (ed.1)

$>$ IEC 61701 (ed.2)

$>$ IEC 62716 (Authority of Northern Cyprus Energy)

\section{Off-Grid Project Example [27]}

Average monthly electricity costs for a house in North Cyprus on $\$ 500$. The following example is given in the off-grid, the installation of the solar system around $20.000 \mathrm{TL}$. The example given to this amount the payment according to the plan, are reimbursed in 5 years. 
Table 4. On-Grid Project Example Proposal [28]

\begin{tabular}{|c|c|c|c|}
\hline $\begin{array}{l}\text { Production } \\
\text { Code }\end{array}$ & Product description & Quantity & Unit \\
\hline 10322 & $\begin{array}{l}\text { - } \quad \text { Solar Modules SOLAR Ecoplus P } 250 . \\
\text { - } \quad+10 \mathrm{Wp} \text { to } 260 \mathrm{Wp} \text { of power Telorans } \\
\text { - } \quad \text { Tyco Connector, } 1640 \text { x } 991 \text { x } 43 \mathrm{~mm} 17.3 \mathrm{~kg} \text {. } \\
\text { - } \quad 10 \text { year performance guarantee of } 90 \% \text {. } \\
\text { - } \quad \text { 25 year performance guarantee of } 80 \% \text {. } \\
\text { - } \quad \text { 12-year product warranty Made in Germany. }\end{array}$ & 16 & Piece \\
\hline 10345 & $\begin{array}{l}\text { - } \quad \text { Solar inverter SMA Sunny Tripower } 6000 \text { TL stp. } \\
\text { - } \quad \text { Multi-array technology, single-phase power-ESS } \\
\text { DC disconnect } \\
\text { - } \quad 98.1 \% \text { efficiency RS-485 (external) Bluetooth. } \\
\text { - } 5 \text { year product warranty. }\end{array}$ & one & Piece \\
\hline 12676 & $\begin{array}{l}\text { - SMA on } 4 \mathrm{~kW} \text { inverter charger device entry. } \\
\text { - } \quad \text { Made in Germany - } 5 \text { year product warranty. }\end{array}$ & one & piece \\
\hline \multirow[t]{2}{*}{9385} & $\begin{array}{l}\text { - } \\
\text { - } \quad \text { Aluminum Construction. } \\
\text { - } \quad \text { Simple Installation is easy and fast installation. } \\
\text { - } \quad 15 \text { years product warranty. }\end{array}$ & one & Set \\
\hline & TOTAL & 5500.00 & Euro \\
\hline
\end{tabular}

\section{Investigation the Regulations in $\mathrm{EU}$ and North Cyprus}

\section{EU Standards for Photovoltaic Solar Energy System}

According to the annual report of the UE Institute, the European Union twenty seven member states and a total population of the world as will be the largest economy in the four understood that the total assets value in $2010,16.3$ trillion (\$) about (501 M) that the European Union (Germany, France, Britain and Italy in[16,29]. In case of EU climate change and provide low-carbon energy such feelings (RE) tries to be sure to secure economic growth and create jobs. The idea is changing climate goals major issue in most EU legislation. World energy consumption and $17 \%$ of the EU's total energy play a major role in the building of about $40 \%$ (Figure 3 ) industry this share shows that it has $34 \%[16,23]$

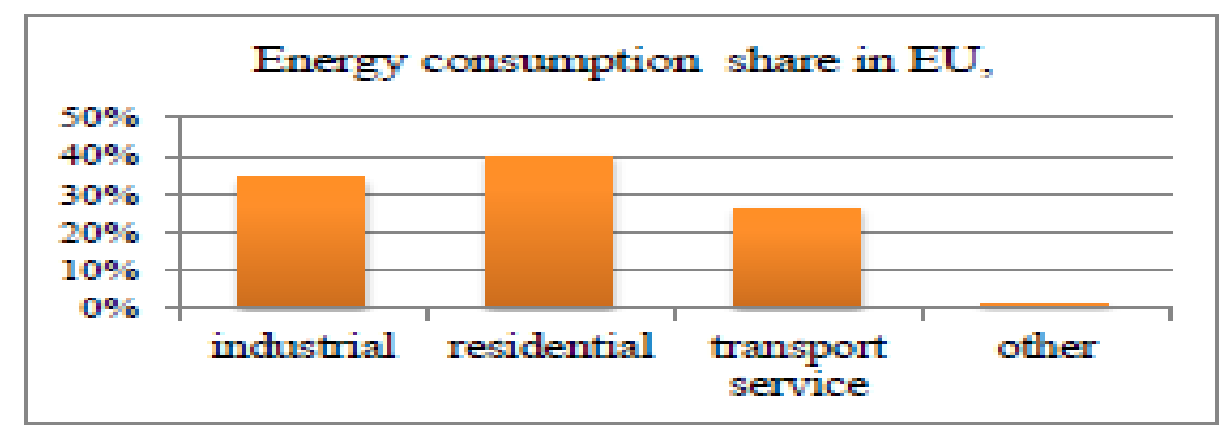

Figure 3. Energy Consumption Share in EU [19].

In addition, Cyprus, Greece, Luxembourg, Ireland and Malta for their country in their energy sector, 70\% of transportation is oil based. Sweden, Norway and Finland and in the Nordic region, the Czech Republic, Central European countries, Slovakia, Hungary and Romania, trust in own energy source to reduce oil and $25 \%$ of the average electricity and gas is replaced with the source if you decide. In addition, Biomass, Austria, Latvia, Estonia, Finland and Sweden the main role in energy supply [16, 19]. 


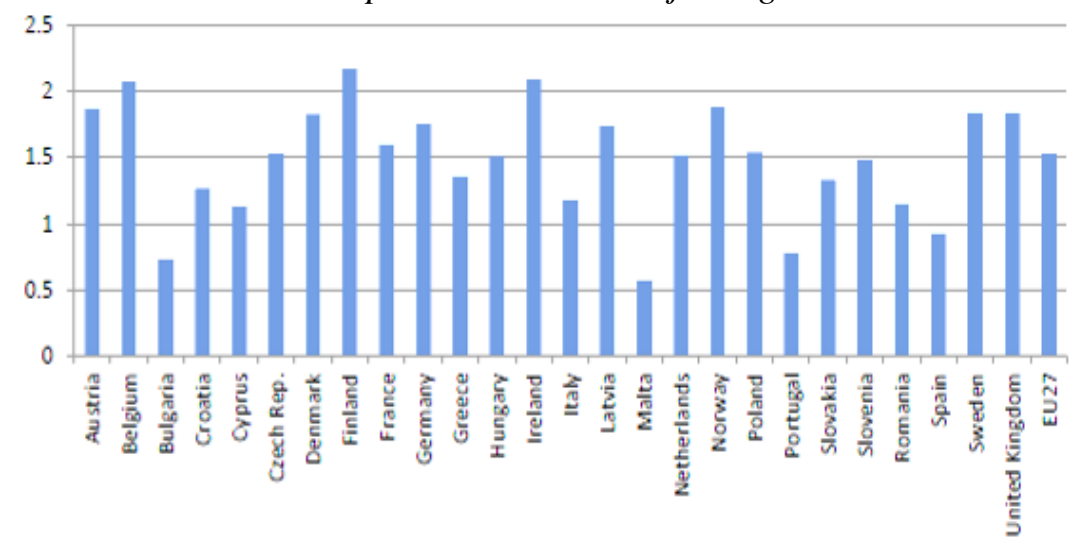

Figure 4. Utilization of Energy in EU [16].

\section{EU PV Market Structure}

It was presented that, The EU place as first major of the Photovoltaic (PV) market in ecumenical by utilize more than $13 \mathrm{GW}$ installed among 2010 till 2011, and total capability of setting up of the PV module in that moment transmuted from 16GW to proximately $30 \mathrm{GW}$ in 2012 [7]. This situation was due to Germany, Italy and the Czech exaggeration of producing in PV industry (Figure 5). On the other hand France rapidly grows and they installed 719 MW in 2010. Afterward Spain disaster in 2009, Spain convalesced self-market moderately, and they reach 369MW annually. In advisement, additionally other components of EU market grow up in sustain mood [29].

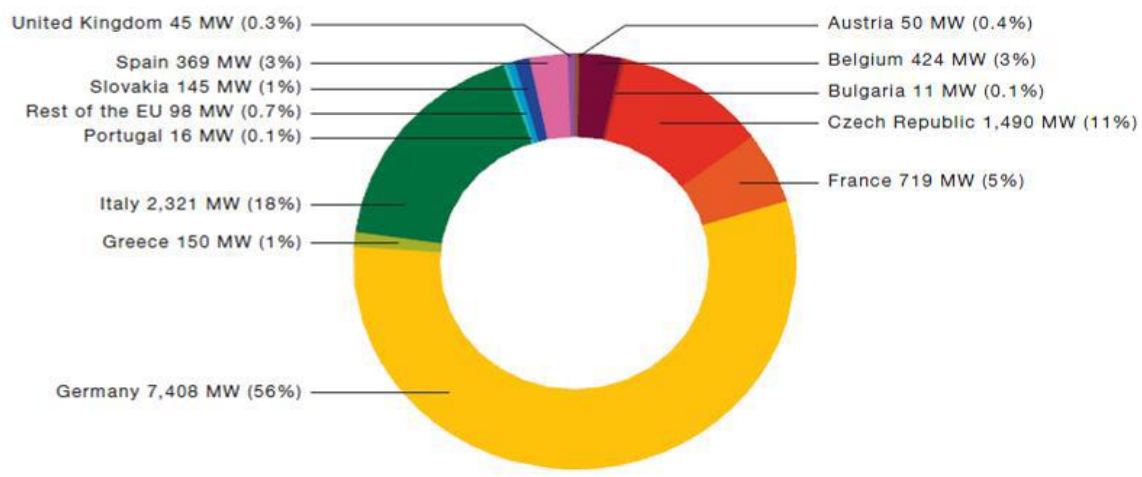

Figure 5. European Market Share 2012[29]

Within the time limit, it was the creation of European market gradually Nordic energy efficiency and adapts production to the outcome legislation. The most advanced and competitive market for energy-saving sectors and sub-sectors in the German market. Their survey of businessmen and financiers in the PV industry to produce 67 Billon $€$, the amount Germany has made the world more than $10 \%$ of all shareholders $[19,29]$.

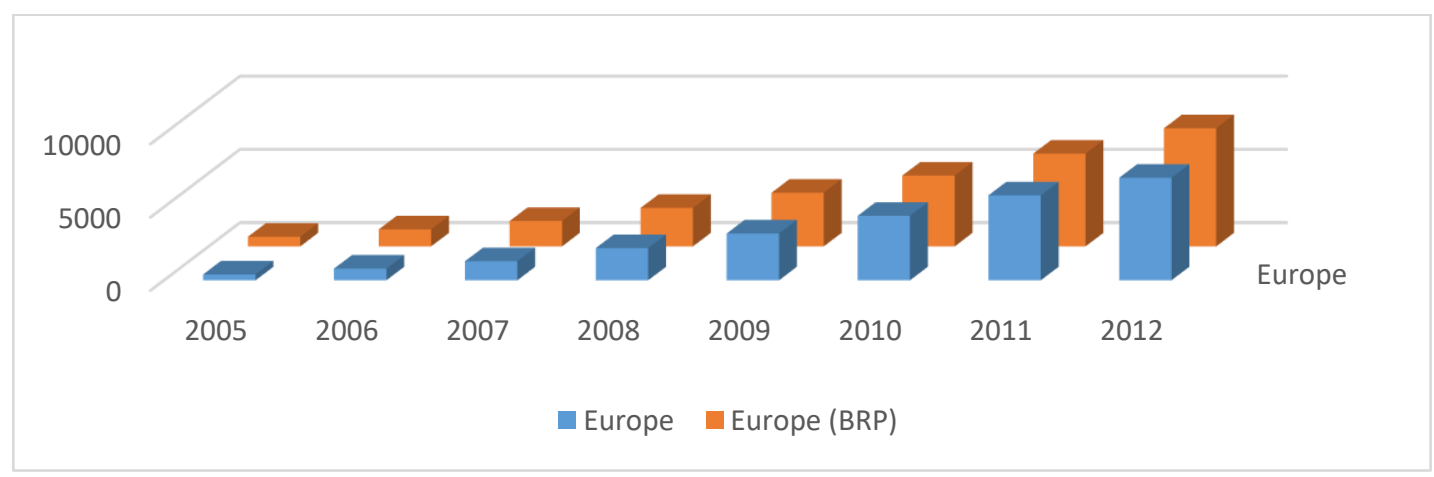

Figure 6. Estimation of the Cumulative Installed PV in EU [16]

\section{EU PV Strategy, Regulation Framework}

PV Policy focused on the promotion of the database market policies. The most important key to the first part of the policy, which rests at the national level, the demand and the government's definition of measure of PV panels' increases the attraction of investors. In addition, it controls the progress of the sales market for the usage of RE. Mutual exchange and knowledge transfer between countries, there is a second objective of the PV Policy database. The focus of European policy, economic incentives to producers and investors in the market by means draws the future of $\mathrm{PV}$ panels and persuasion strategies. 
In 1997, European white paper (committee) 12\% refreshes the energy situation to establish a strategy to double-up existing stock, which is based on the Kyoto Protocol before the European strategy in 2010. Potential members usually focused goal, accordingly, promote renewable energy and increase [30]. Then, "the European Photovoltaic Industry Association (EPIA)" merge (3gwp) and (2010) as the basic installation of the photovoltaic generator and in this market [16] at least "100,000 jobs" builds. 2001 was the starting point of the Green Electricity Directive commission; their aim was to create a framework for promoting PV unfailing use and produce energy in the European Union [31, 32]. It was evaluated 2005-2006 this committee drew existing national models for success in spite of the national targets, this strategy, the Lisbon Strategy mentions three focus functions: First, the Governor Growth, Competitiveness and finally Business [30].

\section{Comparison EU and Northern Cyprus Photovoltaic System}

\section{Comparison EU and Northern Cyprus Advantage}

- Government users PV plant construction and the EU provide financial resources for the installation of the authority of Northern Cyprus.

- There are no restrictions for imports or investment in the PV market in North Cyprus.

- Users do not require special skills to maintain PV at home.

- PV technology research and development to develop their skills.

- PV aids or maintain infrastructure investments to support the liberal or fossil fuel gas and electricity

- High levels of insolation.

- Increased awareness on Climate issues in North Cyprus.
- Covering all key technologies in Europe and has a good spread of PV strong R \& D high level of quality.

- $\quad$ PV attractive and high-tech nature of the country's R \& $\mathrm{D}$ activities in the PV sector, we continuously proposal.

- $\quad$ PV RTD projects are due in EC-funded projects to help build competencies in $\mathrm{R} \& \mathrm{D}$ team with several well-

- $\quad \mathrm{PV}$ in Europe the SME business structure, provides fast reaction to market requirements.

- Thin film cells, organic cells, polymers, BIPV and developed a strong European R \& D in stand-alone

- The existence of PV roof program to stimulate the market.

- European industry strong and BOS system stands alone.

\section{Comparison EU and Northern Cyprus Disadvantage}

- Lack of authority. (difficulties to get permission)

- As architects in charge of Northern Cyprus is not included in PV issues committee.

- It depends on continuous cost reduction.

- Weakness industrial nations.

- Challenges historic buildings or cities, to integrate PV panels

- The regulatory framework in Northern Cyprus constitutes a weakness in the PV market changing frequently.

- A limited number of distribution companies.
- $\quad$ RTD is equal PV technologies and geographical and distribute, to dilute the effort and the key areas may not keep Europe competitive.

- Very few in the country dedicated to the PV program.

- Not enough countries have fully co-ordinated program.

- Policies do not frequent communication between the academic and industrial R \& D.

- $\quad$ Academic and industrial R \& D have different priorities.

- $\quad$ SMEs with European PV companies usually own ground enough snow, new technologies / concept does not make it possible to develop commercial non-emergency.

\section{Investigation of Sustainable Energy in North Cyprus for Future}

Domestic sector and un-renewable resources of Northern Cyprus and the immigrant population is increasing the number of potential limitations constitute the highest finishing position in the PV panel industry to import energy from other countries [17]. Regulations and seedlings Turkish Cypriot's strategy is not yet clear, but according to this part of the market structure, although it will show a great response to this change. However, many countries such as sub-structure change and residential smart grid system contours of the new system are applied to promote the use of PV panels [13]. According to the social analysis of the situation in Northern Cyprus, or get imported in the PV industry will cover the purpose of producing mines in the assembly or the PV definitions. Meanwhile, Northern Cyprus, according to the annual report KIB-TEK's total electricity production capacity of about not all user support, depending on network 346.3 megawatts, high oil and gas prices and grid access restriction Northern Cyprus in renewable energy using rapid growth may have an impact. 


\section{Avrupa Bilim ve Teknoloji Dergisi}

Current economic conditions and high implementation costs of PV technology in North Cyprus due to the use of old fossil fuel technologies in residential facilities, this technology is one of the major difficulties faced when applying. Government energy market in North Cyprus as allowing the use of PV technology is clear that a rapid increase within a year as soon as possible. Monocrystalline PV cells due to its low price and durability available in North Cyprus is the most preferred PV technology is discovered in an interview with the Cyprus Company. In the same study, using non-integrated systems such as PV panels for building façade shading devices to produce electricity is currently in Tuzla, shows that several buildings in Northern Cyprus[33].

This explosion or a way to promote the use of photovoltaic panels in North Cyprus. Therefore, the North Cyprus government to improve the sustainability of the PV market as using a renewable energy source and look into promoting the advantages are put forward. In addition, studies depict how PV modules has used to generate electricity for sustainable building in North Cyprus. Emphasis on the subject and opened at the same time the implementation of PV systems for other applications [34]. The study also opinion on technology, particularly in terms of PV facilities to generate electricity in Northern Cyprus, emphasizes. North Cyprus replay required both possible to install the photovoltaic panels power to meet the electricity needs of the building technological and economically viable. As a long-term perspective on the growth of other countries into account and consequently, proposals to install $\mathrm{PV}$ modules for power generation in North Cyprus is required by the building point of view below.

- There are many areas in the island grid are power outages. But the grid has not reached yet there are a large number of areas in northern Cyprus. All will be in accordance with the power that the living standards of explosion or power plants with PV system requires the use of alternative energy sources and will be cost savings.

- Ownership of Northern Cyprus as an alternative source for generating electricity makes sustainable building solar photovoltaic panels or solar radiation is a good amount, is fortunate to have solar PV electricity bright enough in many areas used for the production of the island; In this regard, the government's own building in order to develop sustainable living in northern Cyprus, giving credit to the owners of the building, including PV power should encourage the use of this important resource.

- Implementation and use of PV power will be useful in reducing the pollution and bearing serves as the public consciousness. Increased public awareness may be useful in determining appropriate policies for long-term sustainable development in Northern Cyprus.

- Northern Cyprus PV power use, climate change, alternative energy sources, will be informed about the availability and use. In terms of education, research PV panels in the future, researchers and policy makers should be encouraged to help; talented and knowledgeable policy makers, researchers, it is desirable for the growth of the country.

- The greatest growth will be in the next few years, solar energy and PV industry.

- To dry Fund and other renewable energy technologies as programs, the photovoltaic system will be the most economical option. When you look at the average carbon footprint of buildings in both commercial and residential markets, it produces 40 to 60 percent of heating most efficient photovoltaic system technology, cooling and hot water.

Finally, the date of the authorities nuclear energy and coal, oil and natural gas from the new railway industries, showed that incentives are playing a major role. There is no doubt that renewable energy sources are not much different. Northern Cyprus in clean energy sector, especially photovoltaic systems, and the need to maintain and deserve more support from the government in the short term to achieve a reasonable growth.

The status of Northern Cyprus has a bright PV market. Northern Cyprus to change the new regulations easily check the current status of the new system are the local people will be found direction, make it readable. The main target countries of the European PV industry and PV use, reduces $\mathrm{CO} 2$ to protect the environment, such as the first generation and finally the review of the business. Although this strategy is focused on the main objectives of Northern Cyprus, but the situation becomes more critical differentiation. It may have an impact on the PV market is the number of population is different. However, over the years cannot be ignored in the amount and on clear days the sun. PV panels make electricity shows us life as the Northern Cyprus issue can easily prepare to observe. In addition, the use of interest and reasons for dividing:

- Environment

- Intense green credit and financial as many feet as there are tariffs.

- In some cases they do not have access to the network.

- Start-up costs and electricity bills is too high.

- PV panel efficiency at 25-year intervals.

Although the dominant bureaucracy as the Italian model, however, this method is not the situation in Cyprus is not yet institutionalized. One legislator refers to the law of Northern Cyprus and has a more punitive approach to prevent the growth of the industry and market. encourage Categories and every industry experts with the existing law and to memorize need to create new jobs, but the definition and separation to make very strategic mistakes and chaos, and in the face of opposition members 20002004.Another point during slow liability rules based on people's information to the path of growth, such as Italy, the main objective of the building, but it was accepted the use of PV panels, so it should be one of the members to organize architectural arrangement if (unfortunately referred to in this regulation.) the addition, BIPV and limits penetration neglect these regulations. This will be sluggish market weakness. Use of e-Government services can reduce the risk of bureaucracy. This is a government that will include information of various IT systems of public service data to develop. In addition, the government schools, government buildings and installation of PV systems in military camps will promote the use of PV panels. Cyprus during the period covered by this strategy, on the other networks are a small and isolated energy system without the potential connection. On the other hand, is still great challenges of Northern Cyprus macroeconomic and microeconomic and employment stage. 
The strategic goal of the country's macroeconomic stability, the favorable economic development and social cohesion. More as a tool to ensure social cohesion, increasing competitiveness of the economy, it remains at the heart of development efforts. In northern Cyprus, regulation and interesting example detailed PV panels mounted and the PV panels but glance using the economists point could make the contract as board producers or subsidies to incent all kinds of rented houses, stop and allows the effects to one assist feature in the long run. Cypriots is to install PV panels Emphasis other nationalities and make a barrier to investment by international companies, thus constitutes the main threat in the regulations. PV panels use special insistence is another obstacle. Revision of photovoltaic systems during contract at this point protraction instant, continuous fund Layouts support is required. The new support plans $20 \mathrm{KW}$ to $100 \mathrm{KW}$ photovoltaic system may be necessary to increase the capacity of the case. PV panel's imported stuff should be noted that imports have to pass through several filters specifically in Northern Cyprus and this filter will increase the initial cost. One of the most important incentives for PV panels economy.

This problem is analyzed and the result was satisfied. Cell type and mounting type depends to compare the size of their 25 -year life of PV cells would pay back the energy used in the production of 1.5-2 years. Is the result if you use your own power, energy bills account for the reduction, in addition, one of the biggest advantages of photovoltaic systems, ease of installation and usually certified installer and is not normally charged.

Northern Cyprus editing and recording not confirm yet. However, confirming the process, although it may take a long time over the issue, but should be formulated as soon as possible, but the European Union, at least not their fault iteration is a good working experience. (FIT) system is an important success factor for the threshold for the profitable operation of a photovoltaic plant (shire) in the calculation of some of the more-tight (break-even point) and 6\% extra risk. The amount of food in the market demand, the tariff does not respond on a regular basis, but small investment, the sector is very sensitive to obstacles. It might affect their interest to use the FIT means changing deep PV panels.

The history of the world shows the maximum use of the subsidy program, subsidies or market (Per-effective) for short-term strategy can be very effective to excite; however, a campaign strategy for sustainable renewable energy should not just depend on the limitations of typical government budget and subsidy organizations. Germany program (EEG-HTDP) without parallel rough guide could certainly have been unsuccessful. a requirement for a current market monitoring system is high[35, 36]. Therefore, great budget are required to start the installation and system. There is a need for national healing approach instead of just monitoring system consistently at a high European level [37]. A few suggestions that North Cyprus body, photovoltaic technology to facilities in urban and rural structures will lead the market indicated. Generally conservative in the field of renewable energy technologies is a field. In addition, a wide network of these assets because it is project-based. This network coordination performance improvement requires the maximization of value leads to experience. Another important concept is to reduce the resistance to adapt new concepts and technologies. The purpose of this policy should be said:

- Licensing and authorization procedures, therefore, briefly mentioned in the previous section related to photovoltaic projects, will reduce the risk of building projects are the main problems encountered in eliminating these barriers.

- Transition and implementation capacity of the cover of a monitoring system and allow the update applicability.

- To increase public awareness and compliance to reduce resistance, the development of a communication strategy is of top priority. This development should target both private and public sectors.

- Certified installers, architects, engineers, and finance and insurance sectors to create the necessary conditions for education.

- The present proposal is based on the basic policy actions aim: technological capacity caps, tariff structure, licensing framework and authorization procedures and monitoring system. Further developments and the establishment of accompanying measures in detail (communication strategies for training and accreditation programs such as installers and development) what to do about.

\section{Conclusion}

Although PV panels are suitable for North Cyprus, but some (such request to meet some houses public services faced costs and high energy demands, no positive issues, population growth, technological developments in rapid growth, you should not think about it, especially the Karpaz region network or have any access to clean and efficient energy) is not suitable for connecting to public networks; It solves many of the significant energy and environmental issues now because renewable energy sources is growing. Surveys and other relevant sources, that one of the major consumers of energy is currently the construction industry, as well as the surrounding area is one of the core contributes to high levels of $\mathrm{CO} 2$ emissions was to observe. Seen in this context, the issue of Northern Cyprus un-consideration of renewable energy is a big concern depends renewable energy to achieve sustainable environmentally friendly buildings. Lack of reliable renewable energy source, requires the use of photovoltaic technology.

The application of this technology in North Cyprus, will lead to social sustainability and therefore cause an increase in the foreign trade market and business opportunities will dramatically increase the sustainability of the building as a unit. In this context, the department of Northern Cyprus benefits of renewable energy sources and research on the important results of these efforts and projects has had to use due to the feasibility of photovoltaic technology. North Cyprus has to be improved the sustainability of the PV market as using a renewable energy source and look into promoting the advantages are put forward. In addition, studies depict how PV modules have used to generate electricity for sustainable building in North Cyprus. It is emphasis on the subject and opened at the same time the implementation of PV systems for other applications. The study also opinion on technology, particularly in terms of PV facilities to generate electricity in Northern Cyprus, emphasizes. North Cyprus replay required both possible to install the photovoltaic panels power to meet the electricity needs of the building technological and economically viable. 


\section{Abbreviations}

KIB-TEK: Cyprus - Turkish Electricity office, EU-RED: Renewable Energy Directive : GHG emission: greenhouse gas emission; NGO: Non-governmental organization; RE: Renewable energy; REA: Renewable Energy Act

\section{Acknowledgements}

We would like to acknowledge all persons contacted during the data collection, who, in different ways, participated in the discussion of this research. Special thanks to the participants of the Cyprus Turkish Electricity office and Northern Cyprus Authorities. Special thanks for Senior Engineers in Cyprus Turkish Engineering Chambers.

\section{Funding}

The research is supported by Cyprus International University and also Both Authors provide the journal fee. Authors' decision is to maximize the alternative energy system in North Cyprus for our new generation. This is the reason that both of them are agreed to make requirements.

\section{Competing interests}

The authors declare that they have no competing interests

\section{References}

[1]Ozerdem., O.C. and Biricik., S. (2011). Overview of energy system and major power quality Problems in north Cyprus, Technical and Physical Problems of Engineering, 8(3): 71-75.

[2]Poullikkas A., (2009). The Cyprus Energy Future, Theopress Ltd. Nicosia, ISBN: 978-9963-9599-4-5.

[3]Bradford, Travis (2006). Solar Revolution: The Economic Transformation of the Global Energy Industry. MIT Press. ISBN $026202604 \mathrm{X}$

[4]Makrides, G., et al. (2010).Temperature behavior of different photovoltaic systems installed in Cyprus and Germany, Solar Energy Materials \& Solar Cells, 93 (2010): 1095-1099.

[5]Randall, Julian (2005). Designing indoor solar products : photovoltaic technologies for AES. Hoboken, New Jersey: J. Wiley \& Sons. ISBN 978-0-470-01661-9.

[6]Oktay, D. (2002). Design with the climate in housing environments: an analysis in Northern Cyprus. Building and Environment, 37 (10), 1003-1012.

[7]Beattie, Donald A. (1997). History and overview of solar heat technologies. Cambridge, Massachusetts: MIT Press. $\underline{\text { ISBN }}$ 978-0585-37263-1.

[8]Bloem, J., Lodib, C., Ciprianoc, J., \&Chemisanab, D. (2012). An outdoor Test Reference Environment for double skin applications of Building Integrated Photovoltaic Systems. Energy and Buildings, 50, 63-73. From: http://www.sciencedirect.com/science/article/pii/S0378778812001715

[9] Baldwin, Sam (20 April 2011) Energy Efficiency \& Renewable Energy: Challenges and Opportunities. Clean Energy SuperCluster Expo Colorado State University. U.S. Department of Energy.

[10] Dickson, H. and Fanelli, M. (2004). What is Geothermal Energy. Pisa, Italy.

[11] Yiannis A. Katsigiannis.(2012). Effect of wind Tribune Classes on the Electricity Production of Wind Farms in Cyprus Island. Nicosia. Hindawi

https://www.researchgate.net/publication/270675705 Effect of Wind Turbine Classes on the Electricity_Production_of Wind_Far ms in Cyprus Island.

[12] Andy Colthorpe (January 10, 2014). PV provided 7\% of Italy's electricity in 2013, says transmission operator. PV-Tech.org. Retrieved 2014-07-31.

[13] Yenilenebilir Enerji Yasast. (2011). Retrieved 8 November, 2016, from

http://tdkb.gov.ct.tr/tr-tr/anasayfa.aspx

[14] Ministry of TRNC Energy. (2011). Renewable Energy Law. Ministry of Turkish Republic of North Cyprus Energy.

[15] Permit Applications for Renewable Energy Systems. (n.d.). Retrieved 3 September, 2016, from http://yek.gov.ct.tr/Formlar

[16] EPIA. (2009). EPIA 2009 Annual Report. European Photovoltaic Industry Association.

[17] Karuppanan Balasubramanian and Akin Cellatoglu (2009); Optimal Utilization of Renewable Energy Resources in North Cyprus: A Proposed Model, Second International Conference on Computer and Electrical Engineering, Dubai.

[18] Bosselman, K. (2008). The Principle of Sustainability: Transforming Law and Governance.

[19] International Energy Agency.(2009). International Energy Agency Annual Report.

[20] Smith, Zachary Alden; Taylor, Katrina D. (2008). Renewable And Alternative Energy Resources: A Reference Handbook. ABCCLIO. p. 174. ISBN 978-1-59884-089-6.

[21] Christopher, Simon. (2006). Alternative Energy: Political, Economic and Social Feasibility. Rowman

[22] Cost of Solar. (n.d.). Retrieved September 1, 2019, from http://www.solarlighting.com/cost-of-solar

[23] Red Electrica de Espana. (2009). Energy Consumption Share in European Union.

[24] Ryan, M. (2010). Photovoltaic Design \& Installation. London: For Dummies.

[25]Off Grid Power Systems. (n.d.). Retrieved June 25, 2019, from http://www.wholesalesolar.com/solar-information/off-grid-living

[26]Make Solar Systems Work Effective (n.d.). Retrieved January 15, 2019, from

http://solpowerpeople.com/make-solar-tracking-systems-cost-effective/

[27] Grid Connected Pv System. (n.d.). Retrieved, 2 June, 2019, from

http://www.alternative-energy-tutorials.com/solar-power/grid-connected-pv-system.html - 35

[28] On-Grid Project Example Proposal. (n.d.). Retrieved 23 August, 2019, from

https://www.ongrid.net/ 
[29] EPIA.(2015). Global Market Outlook For Photovoltaics Until 2015. Retrieved March, 29, 2019, from http://www.slideshare.net/mpenergia/epia-global-market-outlook-for-photovoltaics-until-2015

[30] Krauter, Stefan C. W. (2006); Solar Electric Power Generation - Photovoltaic Energy Systems, Renewable and Green Energy [31] SeiaOrg. (2014). Issues and Policies. Solar Energy Industries Association.

[32] Ron, P. (2007). Green Technology. Collins

[33] Photovoltaic Façade. (n.d.). Retrieved, 2 August, 2019, from

https://www.profils-systemes.com/en/aluminum-joineries/aluminum-facades/tanagra-photovoltaics-facade

[34] Technologies Shaping the Future of Solar Power. (n.d.). Retrieved September 20, 2020, from

https://www.theguardian.com/artanddesign/2015/jun/30/22-bishopgate-skyscraper-london-skyline-development

[35] H Schlemminger, CP Martens, H Wissel, J Martens (2004); German environmental law for practitioners

[36] Marilyn, B. (2011). Climate Change Mitigation, Energy Security. Mit Press

[37] Heinrich, H. (2012). Photovoltaic System Design and Practise.UK: Wiley. 